\title{
Effect of Dietary Monensin Supplementation on Nutrient Intake, Milk Production and Milk Composition of Lactating Murrah Buffaloes
}

\author{
Shiva Gupta ${ }^{1 *}$, Madhu Mohini $^{2}$ and S.S. Thakur ${ }^{2}$ \\ ${ }^{1}$ Veterinary Assistant Surgeon, MP Govt., India \\ ${ }^{2}$ Animal Nutrition Division, NDRI, Karnal-132001, Haryana, India \\ *Corresponding author
}

\section{A B S T R A C T}

\section{Key words \\ Lactating buffalo, \\ Monensin, Nutrient \\ intake, Milk yield, Milk \\ quality \\ Article Info \\ Accepted: \\ 10 July 2018 \\ Available Online: \\ 10 August 2018}

\begin{abstract}
This study evaluated the effect of dietary monensin supplementation on nutrient intake, milk yield and milk quality of Lactating Murrah Buffaloes during early lactation stage receiving concentrate and sugar graze fodder. Twelve lactating Murrah buffaloes (567.50 $\mathrm{kg}$ of live weight; initial days in milk $=52.83 \pm 10.24$; milk yield $=6-8 \mathrm{~kg} / \mathrm{d}$ ) were randomly allocated to two groups depending upon the body weight and days in milk. Both the groups were fed sugar graze and concentrate mixture as a total mixed ration, feed at 70:30 ratio without supplementation (control) or supplemented with monensin $24 \mathrm{mg} / \mathrm{kg}$ of dry matter intake (monensin) for sixty days. The results depicted that dietary monensin supplementation in lactating Murrah buffaloes has no significant effect on nutrients intake, milk production, fat corrected milk yield and milk composition.
\end{abstract}

\section{Introduction}

Ionophore antibiotics word came from their ion-bearing property. These are compounds having ability to form lipid-soluble complexes with cations and thus mediate their transport across lipid barriers which are toxic to many bacteria and protozoa species (Pressman, 1976). Monensin is a monovalent carboxylic polyether ionophore, produced by the fermentation of Streptomyces cinnamonensis (Haney and Hoehn, 1967). It supports bacterial populations that synthesize propionic acid, a precursor of glucose in ruminants, which improves the energy metabolism of the cow (Bergen and Bates, 1984). Monensin is an ionophore that affects gram positive bacteria as it influences ruminal fermentation and causes a shift in the molar proportions of VFA from less acetate and butyrate to more propionate (Duffield et al., 2002). The shift in ruminal VFA production concurs with a reduction in methane losses and as a result, energy efficiency is assumed to be improved. Monensin most commonly used ionophore to improve the efficiency of production (meat and milk) in ruminants (Rodehutscord, 2013). The effects of monensin on milk production and milk composition in dairy cows have been reported by many previous studies. Results on the effects of monensin on milk production are, however, inconsistent in the studies. Some studies have reported that monensin increased milk production, but others have not (Duffield 
et al., 2008). Number of studies reported increasing impact of monensin on milk production between 0.4 and $2.8 \mathrm{~kg}$ of milk/cow/day (Ipharraguerre and Clark, 2003). This effect might be due to an increased supply of glucogenic precursors resulting from changes in the pattern of rumen fermentation (Phipps et al., 2000). Many factors such as parity and body condition score have been reported to influence the impact of monensin on milk production (Melendez et al., 2006). Monensin has been reported to decrease milk fat but this effect was variable among studies (Duffield et al., 2008) and also influenced by many factors such as the dose administered and the fiber, non-fiber carbohydrate and polyunsaturated oils in the diet (Dubuc et al., 2009, AlZahal et al., 2008, Duffield et al., 2003).

\section{Materials and Methods}

The experimental protocol was approved by Institutional Animal Ethics Committee (IAEC/09/16 dated 05.11.2016) of the National Dairy Research Institute, Karnal, India. The study was conducted in the experimental animal shed at Livestock Research Center of National Dairy Research Institute, Karnal, India, located at an altitude of 250 meter above the mean sea level on $29.43^{\circ} \mathrm{N}$ latitude and $72.2^{\circ} \mathrm{E}$ longitude. The maximum ambient temperature goes up to $45^{\circ} \mathrm{C}$ during summer, minimum about $5^{\circ} \mathrm{C}$ during winter, relative humidity varies from 18 to 97 percent with an annual rain fall is approximately $760-960 \mathrm{~mm}$ most of which is received during the months of July to August. (Central Soil Salinity Research Institute, Karnal, Haryana). The present experiment was conducted during mid-December to midFebruary. Twelve lactating Murrah buffaloes having average body weight of (567.50 \pm 44.3 $\mathrm{kg}$ of live weight; initial days-in milk $=52.83$ \pm 10.24 ; milk yield $=6-8 \mathrm{~kg} / \mathrm{d}$ ) were selected from the Institute Livestock Research Centre and identified by numbered ear tags, tethered with nylon rope individually in a wellventilated stall (floor space $=4 \mathrm{~m}^{2}$ per animal) provided with uniform management practices and having facilities for individual feeding. Animals were dewormed using Fenbendazole (Panacur®, Intervet, India) at $10 \mathrm{mg} / \mathrm{kg} \mathrm{BW}$ and treated against ectoparasites using Deltamethrin (Butox ${ }^{\circledR}$ ) spray $10 \mathrm{~d}$ before the commencement of experimental feeding. After an adaptation period of 10 days, animals were randomly divided into two groups of six animals in each on the basis of body weight and days in milk. Both groups were fed ration comprising of green sugar graze fodder chopped at 2-3 cm length and concentrate mixture (in $\mathrm{g} / \mathrm{kg}$ as mixed: maize 330 , groundnut cake 180, mustard oil cake 100 , cotton seed cake 50, wheat bran 200, de-oiled rice bran 60 , bajra 50, mineral mixture 20 and common salt 10) at a ratio 70: 30 without and with monensin supplementation $(24 \mathrm{mg} / \mathrm{kg}$ of dry matter intake) in control and treatment group, respectively for sixty days. Monensin was top dressed on concentrate mixture in the form of Rumensin (Elanco, Division of Eli Lilly and company (NZ Limited), which contains monensin in a concentration of $20 \%$ Mill mix (Equivalent to $200 \mathrm{~g}$ of monensin activity as monensin sodium per $\mathrm{kg}$ ). All animals were provided clean and fresh drinking water twice daily in morning at 10.00 $\mathrm{h}$ and evening at 17:30 h. During sixty days of experiment daily feed intake were recorded. The feed samples were analyzed for proximate principles (AOAC, 2005) and cell wall constituents (Van Soest et al., 1991) and nitrogen $(\mathrm{N})$ determination (Kjeldahl method). Acid detergent lignin was determined by solublization of cellulose with $72 \%(\mathrm{w} / \mathrm{w})$ sulfuric acid in ADF residue. The difference between $\mathrm{ADF}$ and lignin in the sequential analysis was the cellulose content of test feeds. Difference between NDF and ADF was the indirect measure of hemicellulose (HC). The non-fibrous $\mathrm{CHO}$ (NFC) content (\%) was 
estimated directly from the following formula: $100-[\mathrm{CP} \%+\mathrm{EE} \%+\{\mathrm{NDF} \%$ - neutral detergent insoluble CP (NDICP) \% $\}+$ ash\%]. Total digestible nutrients (TDN) was estimated directly from the following formula: $\mathrm{TDN}(\% \mathrm{DM})=(\%$ dig. NFC $)+(\%$ dig. $\mathrm{CP})$ $+(\%$ dig.FA $) \times 2.25+(\%$ dig. NDF $)$ given by (NRC, 2001). Estimation of metabolizable energy (ME) and digestible energy (DE) as per NRC (2001) by following formula:

For feeds with $>3 \%$ EE, ME (Mcal $/ \mathrm{kg})=$ $[1.01 *(\mathrm{DE})-0.45]+0.0046 *(\mathrm{EE}-3)$

For feeds with $<3 \%$ EE, ME (Mcal $/ \mathrm{kg})=$ $1.01 * \mathrm{DE}(\mathrm{Mcal} / \mathrm{kg})-0.45$

Where, DE $(\mathrm{Mcal} / \mathrm{kg})=0.04409 * \mathrm{TDN}(\%)$ and $1 \mathrm{Mcal}=4.184 \mathrm{M}$ joules

During the course of experiment, lactation was studied. The total of morning and evening milk yield of each animal was recorded using circular dial type spring balance, with a capacity of $10 \mathrm{~kg}$ and accuracy of $\pm 0.05 \mathrm{~kg}$. Milk samples were collected into clean polypropylene bottles, at fortnightly intervals from each animal in proportion to milk yield (1/100th) i.e. morning and evening milk samples were pooled and analyzed for milk components like fat, protein, lactose and solid not fat using pre-calibrated automatic milk analyser (Lactostar, FUNKE GERBER, Berlin). The total solids were estimated by oven drying the milk samples $(15-20 \mathrm{~mL})$ at $100^{\circ} \mathrm{C}$ for $12 \mathrm{~h}$. Ash contents were determined following ignition of milk samples $(2 \mathrm{~mL})$ at $550^{\circ} \mathrm{C}$ for $3 \mathrm{~h} .6 \%$ fat corrected milk (FCM) was calculated by the equation of Rice et al., (1970) as follows:

$6 \% \mathrm{FCM}(\mathrm{kg} / \mathrm{d})=0.308 \times$ milk yield $(\mathrm{kg})+$ $(11.54 \times$ fat yield $(\mathrm{kg}) \times$ milk yield $(\mathrm{kg}) \div 10)$

Data collected during study were subjected to the statistical analysis as per Snedecor and
Cochran, 1989. Independent sample t-test was done to find out the significant difference between groups using software package IBM SPSS statistics version 16.0, 2010.

\section{Results and Discussion}

Chemical composition of ingredients of basal diet has been presented in Table 1. The chemical composition of all the ingredients were within normal range as reported previously (Das et al., 2014; Prusty, 2015 and Sharma, 2017).

Nutrients intake during experimental trial are presented in Table 2. There was no difference ( $P>0.05)$ observed in the daily dry matter $(\mathrm{DM})$, crude protein $(\mathrm{CP})$, total digestible nutrient (TDN) intake and energy intake $(\mathrm{kg} / \mathrm{d})$ between the groups. Comparable to the present study, Ali Haimoud et al., (1995) found no change $(\mathrm{P}>0.05)$ in dry matter intake (DMI) of lactating cows were fed ration supplemented with monensin $(33 \mathrm{mg} / \mathrm{kg}$ of DM). Martineau et al., (2007) also reported that DMI was unaffected $(\mathrm{P}>0.05)$ by monensin supplementation $(24 \mathrm{mg} / \mathrm{kg} \mathrm{DM})$ to mid lactating Holstein cows. Similar to these findings Lamba et al., (2013) also observed no difference $(\mathrm{P}>0.05)$ in nutrients intake by monensin $(300 \mathrm{mg} / \mathrm{d})$ supplementation in lactating crossbred cows fed on seasonal green fodder and concentrate mixture. On other hand Cant et al., (1997) found decreased DMI of lactating cows fed ration supplemented with monensin $(14.5 \mathrm{mg} / \mathrm{kg}$ of $\mathrm{DM})$. Different response of monensin supplementation on nutrient intake could be attributed to variation in experimental conditions such as rate of inclusion of monensin, type of offered feedstuffs and different physiological stages and species of animals.

Effect of dietary monensin supplementation on Average fortnightly milk yield $(\mathrm{kg} / \mathrm{d})$ and $6 \%$ FCM in lactating buffaloes is presented in 
Table 3. It was observed that, at the day of start of experiment there was no difference $(\mathrm{P}>0.05)$ between control $(8.08,7.68)$ and treatment $(8.14,7.78)$ group in milk yield $(\mathrm{kg} / \mathrm{d})$ and $6 \%$ FCM yield $(\mathrm{kg} / \mathrm{d})$, respectively. After first fortnight, milk yield $(\mathrm{kg} / \mathrm{d})$ reached to its peak in monensin supplemented group up to second fortnight and thereafter it declined gradually until fourth fortnight but there was no difference $(\mathrm{P}>0.05)$ between the groups. The overall average daily milk yield during sixty days was 8.92 and 9.28 in control and treatment group, respectively and there was no difference $(\mathrm{P}>0.05)$ in both the groups. Similar to present study findings, Lamba et al., (2013) observed that monensin supplementation $(300 \mathrm{mg} / \mathrm{d})$ to lactating crossbred cows for 30 days, has not affected the milk production. However, Helal and Lasheen, (2008) observed that milk yield was increased about $13.3 \%$ in monensin $(400 \mathrm{mg}$ monensin/d/animal) supplemented lactating buffaloes than control.

They also observed that lactose content was significantly $(\mathrm{P}<0.01)$ higher and milk fat content was lower in milk of monensin supplemented lactating buffaloes than control, increased in milk yield might be due to increased milk lactose content in study. In contrast to present study findings, Khattab et al., (2008) found that milk yield $(\mathrm{kg} / \mathrm{d})$ was increased in Egyptian buffaloes on supplementing monensin (400 mg $\operatorname{monen} \sin / \mathrm{h} / \mathrm{d}$ ) for 120 days of lactation period in the diet, it might be due to longer duration of study as compared to present study. Yield of $6 \%$ FCM increased in control and treatment group after first fortnight but there was no difference $(\mathrm{P}>0.05)$ in both the groups. The overall average daily $6 \%$ FCM yield during sixty days was similar between the groups. This similarity in milk production in buffaloes of both the groups is correlated by similar nutrient intake between the groups. Juchem et al., (2004) reported that milk production was unaffected $(\mathrm{P}>0.01)$ but $3.5 \%$ FCM yield was increased $(\mathrm{P}<0.01)$ during the early lactation of Holstein cows by prepartum treatment with Monensin. Similar to findings of present study, Vendraminia et al., (2016) also found no effect on milk yield in mid lactating Holstein cows on supplementation of monensin $(24 \mathrm{mg} / \mathrm{kg} \mathrm{DM})$ with basal diet. In agreement to present findings, Merwe et al., (2001) found no significant effect of monensin supplementation on milk yield and fat corrected milk yield on monensin supplementation in lactating HF cows.

Effect of dietary monensin supplementation on fortnightly milk component (fat, lactose, protein, total solid, SNF \%) and their yield $(\mathrm{kg} / \mathrm{d})$ in lactating buffaloes during sixty days of experiment are listed in Table 4. The fortnightly and average milk fat, milk protein, milk lactose, milk solid not fat (SNF) and milk total solid (TS) percentage were similar $(\mathrm{P}>0.05)$ in both the groups. Average milk fat, milk protein, milk lactose, milk solid not fat (SNF) and milk total solid (TS) were 7.21, $4.21,5.12,10.61$ and $18.19 \%$, respectively in control and 7.14, 4.20, 5.13, 10.60, 18.09\%, respectively in control in treatment group. Average milk fat percentage was lower $(\mathrm{P}>0.05)$ in treatment group as compared to control, this might be due to lowered milk fat by monensin, mediated through interference with biohydrogenation of long-chain fatty acids within the rumen, possibly through its effects on rumen bacteria (Duffield et al., 2002). Osborne et al., (2004) also observed no change in milk fat and protein content in monensin supplemented dairy cows. Ramanzin et al., (1997) also reported that monensin feeding during lactation has no effect on milk lactose content. Similar to findings of present study, Vendraminia et al., (2016) also found no effect on milk composition in mid lactating Holstein cows on supplementation of monensin $(24 \mathrm{mg} / \mathrm{kg} \mathrm{DM})$ with basal diet. 
Table.1 Chemical composition and energy contents of offered feedstuffs

\begin{tabular}{|c|c|c|}
\hline Parameter (\%DM) & Concentrate Mixture & Sugar graze Green fodder \\
\hline DM & 90.39 & 25.21 \\
\hline OM & 94.54 & 90.41 \\
\hline CP & 21.78 & 10.75 \\
\hline EE & 3.9 & 1.73 \\
\hline TA & 5.45 & 9.59 \\
\hline NFC & 44.77 & 17.91 \\
\hline NDF & 24.1 & 60.02 \\
\hline ADF & 11.49 & 36.16 \\
\hline Hemicellulose & 12.6 & 23.86 \\
\hline Cellulose & 6.87 & 30.98 \\
\hline ADL & 3.96 & 5.18 \\
\hline TDN & 76.33 & 56.30 \\
\hline DE (MJ/kg DM) & 14.08 & 10.39 \\
\hline ME (MJ/kg DM) & 12.34 & 8.61 \\
\hline
\end{tabular}

Table.2 Effect of monensin supplementation on nutrients intake in lactating buffaloes

\begin{tabular}{|c|c|c|c|}
\hline Parameter & Control & Treatment & P value \\
\hline DMI (kg/d) & $14.53 \pm 0.27$ & $14.04 \pm 0.18$ & 0.17 \\
\hline CPI (kg/d) & $1.94 \pm 0.06$ & $1.86 \pm 0.03$ & 0.24 \\
\hline TDNI (kg/d) & $8.85 \pm 0.12$ & $8.70 \pm 0.17$ & 0.59 \\
\hline DE (MJ/d) & $163.16 \pm 2.22$ & $160.37 \pm 3.21$ & 0.59 \\
\hline MIE (MJ/d) & $137.44 \pm 1.74$ & $135.53 \pm 2.91$ & 0.68 \\
\hline Millk yield/kg DMI & $0.56 \pm .01$ & $0.58 \pm .03$ & 0.14 \\
\hline
\end{tabular}

Table.3 Effect of dietary monensin supplementation on milk yield, fortnightly milk yield (kg/d) and $6 \% \mathrm{FCM}(\mathrm{kg} / \mathrm{d})$ in lactating buffaloes

\begin{tabular}{|c|c|c|c|c|c|c|}
\hline \multirow{2}{*}{ Fortnight } & \multicolumn{3}{|c|}{ Milk yield (kg/d) } & \multicolumn{3}{c|}{ 6\% FCM (kg/d) } \\
\hline & Control & Treatment & P value & Control & Treatment & P value \\
\hline $\mathbf{0}$ & $8.08 \pm 0.22$ & $8.14 \pm 0.27$ & 0.85 & $7.68 \pm 0.32$ & $7.78 \pm 0.39$ & 0.84 \\
\hline $\mathbf{1}$ & $9.28 \pm 0.36$ & $9.42 \pm 0.42$ & 0.80 & $9.99 \pm 0.70$ & $10.20 \pm 0.74$ & 0.84 \\
\hline $\mathbf{2}$ & $9.11 \pm 0.35$ & $9.68 \pm 0.26$ & 0.22 & $9.73 \pm 0.57$ & $10.79 \pm 0.52$ & 0.20 \\
\hline $\mathbf{3}$ & $9.10 \pm 0.49$ & $9.60 \pm 0.29$ & 0.40 & $9.83 \pm 0.85$ & $10.68 \pm 0.65$ & 0.45 \\
\hline $\mathbf{4}$ & $8.97 \pm 0.26$ & $9.59 \pm 0.30$ & 0.15 & $9.68 \pm 0.50$ & $10.68 \pm 0.62$ & 0.24 \\
\hline $\begin{array}{c}\text { Overall } \\
\text { mean }\end{array}$ & $8.92 \pm 0.28$ & $9.28 \pm 0.28$ & 0.38 & $9.38 \pm 0.46$ & $9.99 \pm 0.51$ & 0.40 \\
\hline
\end{tabular}


Table.4 Effect of monensin supplementation on fortnightly milk components and their yield in lactating buffaloes

\begin{tabular}{|c|c|c|c|c|c|c|c|}
\hline Fortnight & Group & 0 & 1 & 2 & 3 & 4 & $\begin{array}{c}\text { Overall } \\
\text { mean }\end{array}$ \\
\hline \multirow{3}{*}{$\begin{array}{c}\text { Milk fat } \\
\%\end{array}$} & $\mathrm{C}$ & $6.89 \pm 0.13$ & $7.20 \pm 0.18$ & $7.22 \pm 0.19$ & $7.30 \pm 0.18$ & $7.42 \pm 0.17$ & $7.21 \pm 0.14$ \\
\hline & $\mathrm{T}$ & $6.87 \pm 0.15$ & $7.17 \pm 0.14$ & $7.20 \pm 0.17$ & $7.21 \pm 0.22$ & $7.24 \pm 0.19$ & $7.14 \pm 0.16$ \\
\hline & $\mathrm{P}$ value & 0.94 & 0.88 & 0.94 & 0.76 & 0.48 & 0.76 \\
\hline \multirow{3}{*}{$\begin{array}{l}\text { Fat yield } \\
\text { (kg/d) }\end{array}$} & $\mathrm{C}$ & $0.56 \pm 0.01$ & $0.67 \pm 0.03$ & $0.66 \pm 0.02$ & $0.66 \pm 0.03$ & $0.67 \pm 0.02$ & $0.64 \pm 0.02$ \\
\hline & $\mathrm{T}$ & $0.56 \pm 0.02$ & $0.67 \pm 0.02$ & $0.70 \pm 0.02$ & $0.69 \pm 0.03$ & $0.69 \pm 0.03$ & $0.66 \pm 0.02$ \\
\hline & $P$ value & 0.89 & 0.91 & 0.22 & 0.52 & 0.46 & 0.50 \\
\hline \multirow{3}{*}{$\begin{array}{c}\text { Milk } \\
\text { protein \% }\end{array}$} & $\mathrm{C}$ & $4.09 \pm 0.03$ & $4.23 \pm 0.00$ & $4.22 \pm 0.00$ & $4.25 \pm 0.01$ & $4.24 \pm 0.01$ & $4.21 \pm 0.01$ \\
\hline & $\mathrm{T}$ & $4.10 \pm .06$ & $4.21 \pm 0.03$ & $4.20 \pm 0.01$ & $4.24 \pm 0.01$ & $4.23 \pm 0.01$ & $4.20 \pm 0.02$ \\
\hline & $P$ value & 0.93 & 0.55 & 0.24 & 0.34 & 0.48 & 0.45 \\
\hline \multirow{3}{*}{$\begin{array}{c}\text { Protein } \\
\text { yield } \\
\text { (kg/d) } \\
\end{array}$} & $\mathrm{C}$ & $0.33 \pm 0.00$ & $0.39 \pm 0.02$ & $0.38 \pm 0.04$ & $0.39 \pm 0.05$ & $0.38 \pm 0.01$ & $0.38 \pm 0.01$ \\
\hline & $\mathrm{T}$ & $0.33 \pm .01$ & $0.40 \pm 0.04$ & $0.41 \pm 0.03$ & $0.41 \pm 0.01$ & $0.41 \pm 0.01$ & $0.39 \pm 0.01$ \\
\hline & $P$ value & 0.84 & 0.87 & 0.27 & 0.43 & 0.16 & 0.43 \\
\hline \multirow{3}{*}{$\begin{array}{c}\text { Milk } \\
\text { Lactose } \\
(\%) \\
\end{array}$} & $\mathrm{C}$ & $5.09 \pm 0.03$ & $5.11 \pm 0.02$ & $5.12 \pm 0.02$ & $5.14 \pm 0.01$ & $5.15 \pm 0.01$ & $5.12 \pm 0.01$ \\
\hline & $\mathrm{T}$ & $5.10 \pm 0.01$ & $5.12 \pm 0.01$ & $5.13 \pm 0.01$ & $5.13 \pm 0.01$ & $5.14 \pm 0.01$ & $5.13 \pm 0.00$ \\
\hline & $\mathrm{P}$ value & 0.67 & 0.45 & 0.64 & 0.54 & 0.35 & 0.66 \\
\hline \multirow{3}{*}{$\begin{array}{c}\text { Lactose } \\
\text { yield } \\
\text { (kg/d) }\end{array}$} & $\mathrm{C}$ & $0.41 \pm 0.01$ & $0.47 \pm 0.01$ & $0.47 \pm 0.02$ & $0.47 \pm 0.02$ & $0.46 \pm 0.01$ & $0.51 \pm 0.03$ \\
\hline & $\mathrm{T}$ & $0.42 \pm 0.01$ & $0.48 \pm 0.02$ & $0.50 \pm 0.01$ & $0.49 \pm 0.03$ & $0.49 \pm 0.02$ & $0.57 \pm 0.03$ \\
\hline & $\mathrm{P}$ value & 0.79 & 0.75 & 0.19 & 0.41 & 0.17 & 0.23 \\
\hline \multirow{3}{*}{$\begin{array}{c}\text { Milk SNF } \\
(\%)\end{array}$} & $\mathrm{C}$ & $10.52 \pm 0.20$ & $10.62 \pm 0.21$ & $10.64 \pm 0.18$ & $10.63 \pm 0.17$ & $10.63 \pm 0.18$ & $10.61 \pm 0.17$ \\
\hline & $\mathrm{T}$ & $10.53 \pm 0.19$ & $10.63 \pm 0.28$ & $10.64 \pm 0.19$ & $10.62 \pm 0.19$ & $10.59 \pm 0.20$ & $10.60 \pm 0.20$ \\
\hline & $P$ value & 0.97 & 0.97 & 1.00 & 0.97 & 0.88 & 0.98 \\
\hline \multirow{3}{*}{$\begin{array}{c}\text { SNF yield } \\
\text { (kg/d) }\end{array}$} & $\mathrm{C}$ & $0.85 \pm 0.04$ & $0.99 \pm 0.41$ & $0.97 \pm 0.08$ & $0.97 \pm 0.05$ & $0.95 \pm 0.02$ & $0.95 \pm 0.03$ \\
\hline & $\mathrm{T}$ & $0.86 \pm 0.03$ & $1.00 \pm 0.37$ & $1.03 \pm 0.04$ & $1.02 \pm 0.02$ & $1.01 \pm 0.02$ & $0.98 \pm 0.02$ \\
\hline & $\mathrm{P}$ value & 0.89 & 0.82 & 0.13 & 0.40 & 0.06 & 0.35 \\
\hline \multirow{3}{*}{$\begin{array}{c}\text { Milk TS } \\
(\%)\end{array}$} & $\mathrm{C}$ & $17.65 \pm 0.11$ & $18.01 \pm 0.20$ & $18.23 \pm 0.20$ & $18.42 \pm 0.06$ & $18.54 \pm 0.05$ & $18.19 \pm 0.10$ \\
\hline & $\mathrm{T}$ & $17.60 \pm 0.17$ & $18.00 \pm 0.16$ & $18.17 \pm 0.15$ & $18.24 \pm 0.14$ & $18.35 \pm 0.10$ & $18.09 \pm 0.16$ \\
\hline & $\mathrm{P}$ value & 0.95 & 0.96 & 0.84 & 0.26 & 0.11 & 0.53 \\
\hline \multirow{3}{*}{$\begin{array}{c}\text { TS yield } \\
\text { (kg/d) }\end{array}$} & $\mathrm{C}$ & $1.42 \pm 0.03$ & $1.67 \pm 0.07$ & $1.66 \pm 0.06$ & $1.67 \pm 0.09$ & $1.66 \pm 0.05$ & $1.62 \pm 0.05$ \\
\hline & $\mathrm{T}$ & $1.44 \pm 0.05$ & $1.69 \pm 0.07$ & $1.76 \pm 0.05$ & $1.75 \pm 0.06$ & $1.76 \pm 0.06$ & $1.68 \pm 0.05$ \\
\hline & $\mathrm{P}$ value & 0.83 & 0.83 & 0.21 & 0.49 & 0.22 & 0.43 \\
\hline
\end{tabular}

Helal and Lasheen, (2008) observed that milk parameter like total solid, solid not fat and total protein content were not affected $(\mathrm{P}>0.05)$ in monensin $(400 \quad \mathrm{mg}$ monensin/d/animal) supplemented lactating buffaloes than control. In agreement to present findings, Merwe et al., (2001) found no significant effect of monensin supplementation on milk fat and milk protein $\%$ on monensin supplementation in lactating HF cows. Average yield $(\mathrm{kg} / \mathrm{d})$ of milk fat, milk protein milk lactose, milk solid not fat (SNF) and milk total solid (TS) were similar $(\mathrm{P}>0.05)$ in both the groups. Average yield $(\mathrm{kg} / \mathrm{d})$ of milk fat, milk protein milk lactose, milk solid not fat (SNF) and milk total solid 
(TS) were numerically higher in monensin supplemented group it might be due numerically higher milk yield in monensin supplemented group. Juchem et al., (2004) also reported that content and yield of SNF was unaffected $(\mathrm{P}>0.01)$ during the early lactation of Holstein cows by prepartum treatment with Monensin.

It was concluded that monensin supplementation at $24 \mathrm{mg} / \mathrm{kg}$ DMI to lactating buffaloes in early lactation had no significant effect on feed intake, milk production and milk composition. The number of animals per treatment was very small and more long term studies are needed for evaluating efficacy of monensin on milk production and milk composition.

\section{Acknowledgements}

The authors express sincere thanks to the Director, NDRI, Karnal, for providing necessary facilities for this work. Financial assistance for the research was provided by Indian Council of Agricultural Research (ICAR), New Delhi, India.

\section{References}

Ali Haimoud, D., Vernay, M., Bayourthe, C. and Moncoulon, R. 1995. Avoparcin and monensin effects on the digestion of nutrients in dairy cows fed a mixed diet. Can. J. Anim. Sci. 75: 379-385.

AlZahal O., Odongo N. E. and Mutsvangwa T., 2008. Effect of monensin and dietary soybean oil on milk fat percentage and milk fatty acid profile in lactating dairy cows. J Dairy Sci., 91: 1166-1174.

AOAC. 2005. Official Methods of Analysis, 18th ed. Association of Official Analytical Chemists, Washington, DC, USA.
Bergen W. G. and Bates D. B. 1984. Ionophores: Their effect on production efficiency and mode of action. J Anim Sci., 58: 1465-1483.

Cant, J. P., Fredeen, A. H., MacIntyre, T., Gunn, J. and Crowe, N. 1997. Effect of fish oil and monensin on milk composition in dairy cows. Can. J. Anim. Sci., 77: 125-131.

Das, L. K., Kundu, S. S., Kumar, D. and Datt, C. 2014. Assessment of Energy Content of Some Tropical Concentrate Feeds of Ruminants using Model of National Research Council - 2001. Indian J. Sci. Technol., 7(12): 204-212.

Dubuc J., DuTremblay D. and Brodeur M., 2009. A randomized herd-level field study of dietary interactions with monensin on milk fat percentage in dairy cows. J Dairy Sci., 92: 777-781.

Duffield T. F., Rabiee A. R. and Lean I. J. 2008. A meta-analysis of the impact of monensin in lactating dairy cattle. Part 2. Production effects. J Dairy Sci., 91: 1347-1360.

Duffield T., Bagg R., Kelton D., Dick P. and Wilson J. 2003. A field study of dietary interactions with monensin on milk fat percentage in lactating dairy cattle. $J$ Dairy Sci., 86: 4161-4166.

Duffield, T., Bagg, R., DesCoteaux, L., Bouchard, E., Brodeur, m., DuTremblay, D., Keefe, G., LeBlanc, S. and Dick, P. 2002. Prepartum monensin for the reduction of energy associated disease in postpartum dairy cows. $J$. Dairy Sci. 85: 397-405.

Haney M. E. and Hoehn M. M. Monensin, a new biologically active compound. I. 1967. Discovery and isolation. Antimicrob Agents Chemother, 349.

Helal, F. I. S. and Lasheen, M. A. 2008. The Productive Performance of Egyptian Dairy Buffaloes Receiving Biosynthetic Bovine Somatotropin (rbST) with or 
Without Monensin. American Eurasian J. Agric. \& Environ. Sci., 3(5): 771-777. Ipharraguerre I. R. and Clark J. H. 2003.Usefulness of ionophores for lactating dairy cows: A review. Anim Feed Sci Technol., 106: 39-57.

Juchem, S. O., Santos, F. A. P., Imaizumi, H., Pires, A. V. and Barnabe, E. C. 2004 Production and Blood Parameters of Holstein Cows Treated Prepartum with Sodium Monensin or Propylene Glycol. J. Dairy Sci., 87: 680-689.

Khattab, H. M. M., El-Sayed H. M., El-Nor, S. A. H. A., El-Alamy, H. A. and ElGawad, R. M. A. A. 2008. Impact of bovine somatotropin and monensin on productive performance of Egyptian buffaloes. Int. J. Dairy Sci., 3(1): 11-19.

Lamba, J. S., Grewal, R. S., Ahuja, C. S., Malhotra, P. and Tyagi, N. 2013. Effect of Monensin on the Milk Production, Milk Composition, Rumen Metabolism and Blood Biochemical Profile in Crossbred Cows. Indian J. Anim. Nutr., 30(1): 38-42.

Martineau, R., Benchaar, C., Petit, H. V., Lapierre, H., Ouellet, D. R., Pellerin, D. and Berthiaume, R. 2007. Effects of Lasalocid or Monensin Supplementation on Digestion, Ruminal Fermentation, Blood Metabolites, and Milk Production of Lactating Dairy Cows. J. Dairy Sci., 90: 5714-5725.

Melendez P., Goff J. P., Risco C. A., Archbald L. F., Little R. C., Donovan G. A. 2006. Effect of administration of a controlled-release monensin capsule on incidence of calving-related disorders, fertility, and milk yield in dairy cows. Am J Vet Res., 67: 537-543.

Merwe, B. J. V., Dugmore, T. J. and Walsh, K. P. 2001. The effect of monensin on milk production, milk urea nitrogen and body condition score of grazing dairy cows. South African J. Anim. Sci., 31(1): 49-55.
NRC. 2001. Nutrient Requirements of Dairy Cattle: Seventh Revised Edition. National Research Council, National Academy of Sciences. Washington, D.C.

Osborne, J. K., Mutsvangwa, T., Azahal, O., Duffield, T. F., Bagg, R., Dick, P., Vassie, G., and McBride, B. W. 2004. Effect of monensin on ruminal forage degradability and total tract diet digestibility in lactating dairy cows during grain induced sub-acute ruminal acidosis. J.Dairy Sci., 87: 2137-2794.

Phipps R. H., Wilkinson J. I. D., Jonker L. J., Tarrant M., Jones A. K. and Hodge A. 2000. Effect of monensin on milk production of Holstein-Friesan dairy cows. J Dairy Sci., 83: 2789-2794.

Pressman, B. C. 1976. Biological applications of ionophores. Annu. Rev. Biochem., 45: 501-507.

Prusty, S. 2015. Metabolizable protein and energy requirements for buffalo calves fed on low methane producing rations. Ph.D. thesis, NDRI, Deemed University, Karnal (Haryana), India.

Ramanzin, M., Baioloni, L., Schiavon, S. and Bittante, G., 1997. Effect of monensin on milk production and efficiency of dairy cows fed two diets differing in forage to concentrate rations. J. Dairy Sci., 80: 1136-1142.

Rice, V. A., Andrews, F. N., Warnwick and Legates, J. E. 1970. Breeding and Improvement of Farm Animals, 6th edn. Tata Mc Grah Hill Publishing Company Ltd. Bombay, India.

Rodehutscord, M. 2013. Effects of monensin and tannin extract supplementation on methane production and other criteria of rumen fermentation in vitro and in longterm studies with sheep. Dissertation. Universität Hohenheim.

Sharma, N. 2017. Metabolic profiling and nutrient utilization in transition cows fed DCAD based diet supplemented 
with oil and polyherbal preparation. M.V.Sc thesis. NDRI, Deemed University, Karnal (Haryana), India.

Snedecor, G. W. and Cochran, W. G. 1989. Statistical Methods, 8th ed. Oxford and IBH Publishing Company, New Delhi.

Van Soest, P. J., Robertson, J. B. and Lewis, B. A. 1991. Methods for dietary fiber, neutral detergent fiber, and non-starch polysaccharides in relation to animal nutrition. J. Dairy Sci., 74: 3583-3597.
Vendraminia, T. H. A., Takiyaa, C. S., Silvaa, T. H., Zanferaria, F., Rentasa, M. F., Bertonia, J. C. Consentinia, C. E. C. Gardinala, R., Acedob, T. S. and Rennóa, F. P. 2016. Effects of a blend of essential oils, chitosan or monensin onnutrient intake and digestibility of lactating dairy cows. Anim. Feed Sci. Techno, 214: 12-21.

\section{How to cite this article:}

Shiva Gupta, Madhu Mohini and Thakur, S.S. 2018. Effect of Dietary Monensin Supplementation on Nutrient Intake, Milk Production and Milk Composition of Lactating Murrah Buffaloes. Int.J.Curr.Microbiol.App.Sci. 7(08): 1429-1437. doi: https://doi.org/10.20546/ijcmas.2018.708.164 